ISSN 0853-8697

\title{
VALIDATION OF ERGONOMICS MODEL FOR ESTIMATING WORK PRODUCTIVITY AND QUALITY IN MANUAL HANDLING ACTIVITIES
}

\author{
Hartomo', Azmi Hassan', Che Hassan Che Haron² \\ 1D epartement of Industrial Engineering Faculty of Industrial Technology \\ Islamic U niversity of Indonesia Y ogyakarta \\ 2D epartement of M echanical Engineering Faculty of Engineering \\ $\mathrm{N}$ ational University of $\mathrm{M}$ alaysia \\ E-mail: hart_tom68@yahoo.com, speah@vlsi.eng.ukm.my
}

\begin{abstract}
ABSTRAK
Tujuan penelitian ini adalah melakukan uji validasi model ergonomi tentang waktu pergerakan kerja untuk mengukur produktivitas dan kualitas kerja. Model ini dikembangkan berdasarkan interaksi antara parameter-parameter postur kerja, masa beban dan dimensi tempat kerja. Ekseperimen dilakukan untuk mensimulasikan aktivitas pengangkatan beban dengan melibatkan pekerja yang berusia diantara 21 hingga 25 tahun. Pekerja tersebut diinstruksikan untuk mengangkat tiga masa beban yang berbeda yaitu 2 kilogram, 6 kilogram dan 10 kilogram ke atas meja kerja dengan tinggi masing-masing 55 $\mathrm{cm}$ dan $76 \mathrm{~cm}$ dengan menggunakan dua postur pengangkatan, postur membungkuk (Stooping) dan postur berjongkok (Squating). A ktivitas pengangkatan ini direkam dengan menggunakan handycam dan kalibrasi dilakukan untuk menentukan skala gambar terhadap benda nyata. U ji statistik t digunakan untuk menguji kesahihan model. Hasil uji ini menunjukkan bahwa tidak ada perbedaan yang siginifikan antara waktu pergerakan nyata dengan waktu pergerakan yang ditentukan dengan model. Dengan demikian model yang dikembangkan adalah valid pada tingkat signifikansi $1 \%, 5 \%$ dan $10 \%$ sehingga model dapat diaplikasikan.
\end{abstract}

Kata kunci: produktivitas dan kualitas kerja, waktu pergerakan, postur kerja, model ergonomi.

\section{INTRODUCTION}

An important aspect of work productivity and quality measurement in line production involves the determination of cycle time. In the man-machine interaction, the calculation of cycle time requires the determination of motion time of worker and operation time of machine. The motion time of worker is affected by interaction of the working posture, mass of load and dimension of workplace. This interaction resulted in comfortably of work such that it will improve the work productivity and quality of worker [5].

A model was proposed to determinate motion time of body of worker. It was developed based on bio-dynamics especially related in the energy-work principles. Development of model involved three variables. Those are distance of motion, mass of load and w orking posture. The distance of motion was determined 
based on dimension of workplace and type of motion. Mass of load determinate a kind of job used. And work posture is related to method of work.

Improper posture and motion of work will affect the speed of body motion. Eventually, it will produce wasting time of work [4]. As well as they cause impairment or mechanical stress at body worker and lost of energy [2]. For example; to reach an object whose is located lower than knee position. It causes the trunk flexing forward extremely. This motion will take along time and reduce work productivity and quality [10].

The objective in this study is to validate the body motion time model for estimating work productivity and quality. It is compared with the real motion time such that the measurement model developed could be applied to actual working motion.

\section{DESCRIPTION OF THE BODY MOTION TIME MODEL}

Metabolism is the chemical process by which foodstuffs are converted into heat or mechanical energy. The large muscles of the body convert approximately 30 percent of the energy liberated into mechanical w ork, while the other 70 percent is given off as heat [7].

Assuming the energy which is used by the muscles for producing mechanical work $\left(\mathrm{W}_{\mathrm{m}}\right)$ and heat $(\mathrm{H})$ is the total work and if mechanical work is the change of kinetic energy, then the total work is given approximately by:

$$
W_{T}=\left(T K_{f}-T K_{i}\right)+H
$$

And if the heat that is lost is percentage of total work (k) such that equation (1) become:

$$
W_{T}=\left(T K_{f}-T K_{i}\right)+k W_{T}
$$

and,

$$
\mathrm{TK}_{\mathrm{f}}-\mathrm{TK}_{\mathrm{i}}=\left|(1-\mathrm{k}) \mathrm{W}_{\mathrm{T}}\right|
$$

where a negative effect is neglected by absolute sign.

A task is consisted of some motions of the body. Every motion requires a certain time, $t_{m}$, to move from one point to another. The calculation of the cycle time $(\mathrm{t})$ is determined based on sum of operation time of machine $\left(\mathrm{t}_{\mathrm{om}}\right)$ and the total of motion time. This cycle time can be expressed as follow:

$$
t=t_{o m}+\sum_{m=1}^{M} t_{m}
$$


A motion time of the mth motion can be obtained by assuming a body motion as a particle. Based on equation (3), this expression of a motion time for the mth motion is given:

$$
t_{m}=\frac{\sum_{j=1}^{J} S_{(i f) j}}{\sqrt{\frac{\left.2(1-k) \sum_{j=1}^{J} \sum_{l=1}^{L}\left|W_{T(I, j)}\right|\right]}{\sum_{l=1}^{L}\left(m_{l}+\frac{l_{l}}{r_{I}{ }^{2}}\right)}}}
$$

where $t_{m}=$ motion time of the mth motion (second), $S_{(\text {iffj }}=$ distance of the ith position to the fth position at the jth frame, $l_{1}=$ the moment of inertia of Ith body segment, $m_{l}=$ mass of the lth body segment, $r_{l}=$ length of Ith body segment, $k=$ percentage of the heat, $\mathrm{W}_{T(\mathrm{l}, \mathrm{j})}=$ the total work of the lth body segment at $\mathrm{jth}$ frame.

\section{MATERIALS AND METHOD}

\subsection{Subjects}

Fifteen healthy workers (all is man) is used a sample in this study. We called as subjects in this paper. All subjects had no history of injury or musculoskeletal disorders. The relevant characteristics of subjects are presented in Table 1. Full description about the purpose and the protocol of the study was provided to the subjects and their consents were obtained. Prior to the experiment, the subjects were demonstrated on the procedures and were asked to practice before the real study.

Table 1. Characteristics of subjects

\begin{tabular}{llccc}
\hline Gender & Stats. & Age & Weight $(\mathrm{kg})$ & Height $(\mathrm{cm})$ \\
\hline \multirow{3}{*}{ Males } & & & & \\
$\mathrm{N}=15$ & Mean & 22.4 & 62.6 & 171.8 \\
& SD & 1.67 & 9.74 & 3.35 \\
& Min & 21 & 51 & 169 \\
& Max & 25 & 78 & 177 \\
\hline
\end{tabular}

\subsection{A pparatus}

External load, which consists of three boxes ( $32 \mathrm{~cm} \times 25 \mathrm{~cm} \times 20 \mathrm{~cm})$, two tables $76 \mathrm{~cm}$ and $55 \mathrm{~cm}$ in height were used in the experiment. Digital Video Camera Recorder Sony DCR-TRV20E was used to capture the subjects during the lifting experiments. The recording films was saved in a Sony mini DV Digital Video Cassette DVM60 ME and later download to PC using Media Studio Pro version 6.0 Video Edition software with file format of avi Geometric data of body posture was then identified to two-dimension ( $x-y$ coordinate) using movie plotter software. Stopwatch was used to measure the actual time. 


\subsection{Design of Experiment}

Simulation of the lifting activities was executed in the ergonomics laboratory. It was divided two sessions; exercises and practical session. A box was located $28.5 \mathrm{~cm}$ from the center of body to center of mass of box. Height of destination is $76 \mathrm{~cm}$ and $55 \mathrm{~cm}$ and placed to the maximum reach. This is used for avoiding the extended flexion of trunk when the subject placing a box at thetable.

A video recorder was set on sagital plan (i.e. side view). It was placed 400 $\mathrm{cm}$ from the object. The height of video recorder was set at $79 \mathrm{~cm}$ from floor. Each body joint of the subject was attached with a marker.

\subsection{Procedure}

At the onset of experimental session, the subjects' anthropometrics measurements were taken. Weight and stature of body were measured. As well as weight and length of segment (i.e. forearm-hand, upper arm, trunk, upper leg and lower leg) were determined based on percentage of weight and stature of body [8].

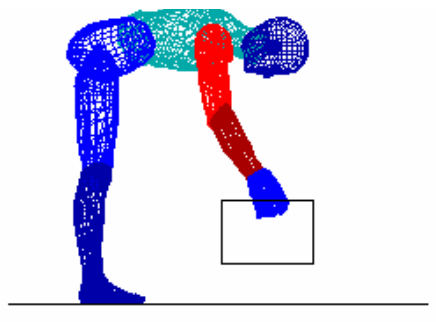

Back Lift

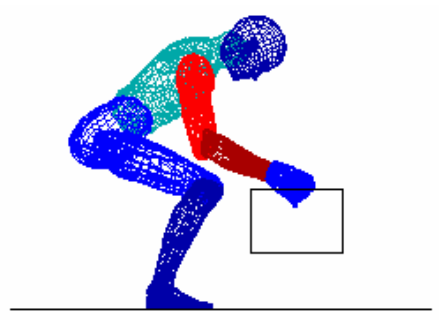

Leg Lift

Figure 1. Diagram of the two lifting techniques

The subjects were then instructed to correct their lifting procedure. Basically they were instructed not to jerk the load and to keep the motion as smooth as possible. Speed of lifting was also set at medium. The subjects were told to lift the loads manually for two different techniques, (i.e. back lift and leg lift). They were allowed to familiarize with the lifting techniques. The weight of each box is set at 2 $\mathrm{kg}, 6 \mathrm{~kg}$ and $10 \mathrm{~kg}$. They are required to lift the load while grasping both of the handles. Each subject was then allowed at approximately 10 min to warm up or exercise

Following the exercise and familiarization period, the subject's hand, elbow, shoulder, hip, knee and ankle and also center mass of box were identified using paper reflective markers. The subject was then instructed to lift the load $(2 \mathrm{~kg}, 6 \mathrm{~kg}$, $10 \mathrm{~kg}$ ) at the medium speed for both of lifting techniques up to three times respectively. The subject was given approximately 10 min to rest between each lifting. 


\subsection{Calibration}

Prior to the actual experiment, the calibration was conducted to determine the scale of image over the real object. Cylindrical tube was used in this session. Mathematical equation was developed to calculate the scale. This equation will identify the actual coordinates of the subjects in two dimensions ( $x-y)$.

\subsection{Biomechanical M odel}

The body was considered to consist of five main segments: forearm-hand, upper arm, trunk including the neck and head, upper leg and lower leg. For the analysis of biomechanical force and torques, the "free-body diagram" concept was utilized.

The anthropometrics data derived from Dempster [1] were used to determine the weights, center of mass and moment of inertia of the joints or segments as well as the trunk, head and neck [9]. To determine these anthropometric variables for the head, neck and trunk above L5/ S1, it was assumed that $65.5 \%$ of the weight of the trunk was above the L5/ S1 level [6].

After determining the center-point and angle of the body joints or also called segments, the linear (horizontal and vertical) and angular accelerations were obtained as the second derivates of positions and angles.

The forcetorque analysis began from segment $\mathrm{i}$. The components of the reactive force across and the torque (moment) around the related joint $\left(R_{j x}, R_{j y}, M_{j}\right)$ were obtained from equations (1)-(3):

$$
\begin{aligned}
R_{j x}= & m_{i x} a_{i x}+R_{(j-1) x} \\
R_{j y}= & m_{i}\left(g+a_{i y}\right)+R_{(j-1) y} \\
M_{j}= & M_{j-1}+j C M_{i}\left(\cos \theta_{j}\right) m_{i j} g+j C M_{i}\left(\cos \theta_{j}\right) m_{i j} a_{i y}+j C M_{i}\left(\sin \theta_{j}\right) m_{i} a_{i x} \\
& +j j-1\left(\cos \theta_{j}\right) R_{(j-1) y}+j j-1\left(\sin \theta_{j}\right) R_{(j-1) x}+I_{i} \alpha_{l}
\end{aligned}
$$

where

$$
\begin{aligned}
& \mathrm{mi}_{\mathrm{i}} \quad=\text { mass of segment } \mathrm{i} \\
& R_{j x}, R_{j y} \quad=\text { the reactive force at joint } j \text { in the } x \text { and } y \text { direction } \\
& \mathrm{R}_{(j-1) \mathrm{y}}, \mathrm{R}_{(j-1) \mathrm{x}}=\text { the reactive force at the adjacent joint }(\mathrm{j}-1) \text { in the } \mathrm{x} \text { and } \mathrm{y} \text { direction } \\
& \mathrm{aix}_{\mathrm{ix}} \mathrm{a}_{\mathrm{i} y}=\text { the instantaneous linear acceleration } \mathrm{x} \text { or } \mathrm{y} \text { component of segments } \mathrm{i} \\
& \text { at the center of mass. } \\
& \text { g =acceleration due to gravity } \\
& \mathrm{M}_{\mathrm{j}} \quad \quad=\text { the load moment at each joint } \mathrm{j} \\
& \mathrm{M}_{\mathrm{j}-1} \quad=\text { the load moment at the adjacent joint } \mathrm{j}-1 \\
& \mathrm{jCM}_{\mathrm{i}} \quad=\text { the distance from joint } \mathrm{j} \text { to the center of mass of segment } \mathrm{i} \\
& \theta_{\mathrm{j}} \quad=\text { the postural angles of each joint } \mathrm{j} \text { relative to the horizontal right } \\
& \text { axis } \\
& \mathrm{j} \mathrm{j}-1=\text { the body segment length } \\
& \mathrm{I}_{\mathrm{i}} \quad=\text { the moment of inertia of segment } \mathrm{i} \text { about an axis through the center } \\
& \text { of mass normal to sagital plane of motion }
\end{aligned}
$$


$\alpha_{j} \quad=$ the angular acceleration of the segment about joint $\mathrm{j}$ relative to the horizontal.

The net mechanical work (W) done by agonist-antagonist muscle pair upon each body segment must be specified during a particular period of time. It may be cal culated from the multiplication of moment and difference angle for each joint:

$W_{j}=M_{j} \times\left(\theta_{j+1}-\theta_{j-1}\right)$

where

$\mathrm{W}_{\mathrm{j}} \quad=$ the mechanical work at each joint $\mathrm{j}$

$\theta_{j+1}$ and $\theta_{j-1}=$ the postural angles of each joint $\mathrm{j}$ relative to the horizontal right axis during a particular period of time $(t+1$ and $t-1)$.

\subsection{Statistical analysis}

The statistical analysis was based on one recording of each technically correct lift from each subject. It was performed for validate the model developed. The results of each technique were compared with the actual motion time using the $\mathrm{t}-$ test.

\section{RESULT}

Table 2 presents the result of the two-tail t-test at the significant level 1\%, $5 \%$ and $10 \%$. The calculated motion time by the model is compared with the actual motion time.

Table 2. The t-test for validating the model developed

\begin{tabular}{|c|c|c|c|c|c|c|c|c|c|}
\hline \multirow{2}{*}{ Parameter } & \multicolumn{2}{|c|}{ M odel } & \multicolumn{2}{|c|}{ Actual } & \multirow{2}{*}{ ME } & \multirow{2}{*}{ t-test } & \multicolumn{3}{|c|}{ Significant Level } \\
\hline & M ean & SD & M ean & SD & & & $10 \%$ & $5 \%$ & $1 \%$ \\
\hline $\begin{array}{l}\text { Squatting } \\
\text { Posture }\end{array}$ & & & & & & & & & \\
\hline $55 \mathrm{~cm} ; 10 \mathrm{~kg}$ & 1.0068 & 0.0861 & 1.1382 & 0.0962 & -0.1314 & -2.8336 & $\mathrm{~S}$ & $\mathrm{~S}$ & TS \\
\hline $55 \mathrm{~cm} ; 6 \mathrm{~kg}$ & 1.0411 & 0.0848 & 1.1193 & 0.0436 & -0.0782 & -2.0940 & $\mathrm{~S}$ & TS & TS \\
\hline $55 \mathrm{~cm} ; 2 \mathrm{~kg}$ & 1.0792 & 0.0698 & 1.1080 & 0.1028 & -0.0289 & -1.2275 & TS & TS & TS \\
\hline 76 cm;10kg & 1.0383 & 0.0820 & 1.1418 & 0.0776 & -0.1035 & -2.7915 & $\mathrm{~S}$ & $\mathrm{~S}$ & TS \\
\hline $76 \mathrm{~cm} ; 6 \mathrm{~kg}$ & 1.1268 & 0.0869 & 1.1735 & 0.0826 & -0.0467 & -1.2840 & TS & TS & TS \\
\hline 76 cm; 2 kg & 1.2471 & 0.0869 & 1.1953 & 0.0812 & 0.0518 & 1.3110 & TS & TS & TS \\
\hline $\begin{array}{l}\text { Stooping } \\
\text { Posture }\end{array}$ & & & & & & & & & \\
\hline $55 \mathrm{~cm} ; 10 \mathrm{~kg}$ & 0.9981 & 0.1233 & 1.1577 & 0.0725 & -0.1596 & -3.0259 & $\mathrm{~S}$ & S & TS \\
\hline $55 \mathrm{~cm} ; 6 \mathrm{~kg}$ & 1.0524 & 0.0790 & 1.1305 & 0.0531 & -0.0780 & -2.2897 & S & TS & TS \\
\hline $55 \mathrm{~cm} ; 2 \mathrm{~kg}$ & 1.1126 & 0.2125 & 1.2417 & 0.0856 & -0.1291 & -1.5604 & TS & TS & TS \\
\hline $76 \mathrm{~cm} ; 10 \mathrm{~kg}$ & 1.0671 & 0.1081 & 1.1453 & 0.0561 & -0.0782 & -3.0863 & $\mathrm{~S}$ & $\mathrm{~S}$ & TS \\
\hline $76 \mathrm{~cm} ; 6 \mathrm{~kg}$ & 1.1156 & 0.1174 & 1.1899 & 0.0477 & -0.0742 & -1.7533 & TS & TS & TS \\
\hline $76 \mathrm{~cm} ; 2 \mathrm{~kg}$ & 1.2811 & 0.1692 & 1.2100 & 0.0604 & -0.0711 & 1.1948 & TS & TS & TS \\
\hline
\end{tabular}

$\mathrm{N}$ otes: S : Significant difference; TS: N ot significant difference

Squatting posture: For lifting $10 \mathrm{~kg}$ weight of load from floor to $55 \mathrm{~cm}$ height, the result of the t- test shows that there is significant difference between the actual 
motion time and the calculated motion time by the model at significant level 10 percent and 5 percent. At significant level $1 \%$, the model has no significant difference. This t-test also shows that there is significant difference for lifting $6 \mathrm{~kg}$ weight of load at significant level $10 \%$ but there is no significant difference at significant level $5 \%$ and $1 \%$. On the other hand for lifting $2 \mathrm{~kg}$ weight of load, thettest shows that there is no significant difference between the actual motion time and the calculated motion time by the model at whole significant level.

For lifting $10 \mathrm{~kg}$ weight of load from floor to $76 \mathrm{~cm}$ height, the t-test shows the similar condition with when it is lifted to $55 \mathrm{~cm}$ height. But the t- test shows a different condition while lifting $6 \mathrm{~kg}$ weight of load to $76 \mathrm{~cm}$ height. The result of this statistical test was identifying that there is no significant difference at $10 \%, 5 \%$ and $1 \%$ significant level. As well as the t-test results in that there is no there is no significant difference at $10 \%, 5 \%$ and $1 \%$ significant level for lifting $2 \mathrm{~kg}$ weight of load.

Stooping Posture: The result of the t-test shows a similar result with squatting posture. Whether for lifting $10 \mathrm{~kg}, 6 \mathrm{~kg}$ and $2 \mathrm{~kg}$ weight of load from floor to $55 \mathrm{~cm}$ height or to $76 \mathrm{~cm}$ height. It can be, therefore, concluded that hypothesis $\mathrm{H}_{0}$ was accepted which there is no significant difference between the actual motion time and the calculated motion time by the model at the whole significant level for both lifting posture, stooping and squatting.

\section{DISCUSSION}

Model developed is model of work productivity and quality measurement. It focused on motion time of the body worker and involved three variables. Those variables are distance of motion, mass of load and working posture. The distance of motion shows length of motion from the origin position to the destination position. While mass of load and working posture show mechanical stress on the body worker.

Refers to result of the t- statistical test at Table 2, model have capability to measure motion time of the body worker. It is shown that there is no significant difference between means of the actual motion timeand the calculated motion time by model whether for squatting posture or stooping posture. The distance of motion plays an important role for calculating the motion time. It is determined by motion path of the outer body part. The path of motion depends on mass of load that is moved and dimension of workplace. Figure 2 shows effect of load to the motion path or the distance of motion.

Figure 2.(a) and Figure 2.(b), whether for squatting posture or stooping posture, show that the more weight of load the longer of motion path or distance. A worker who tends to lift loads cl oser to his body causes this condition such that it causes probably the longer motion time with assuming speed of motion is constant. On the other hand, figure 3 shows different condition. The developed model produces the shorter body motion time when the distance or motion path increase. It is caused by the effect of mechanical work occurred at the body worker.

The cal culated motion time by the developed model is based on the absolute value of mechanical work. Hafez and Ayoub [3] explained that the use of absolute 
value, whether for positive or negative mechanical work, because of the moment reaction of joint is resulted from the concentric and eccentric muscles contraction. Two kind of this muscle contraction produces mechanical work that they present a form of stress at musculoskeletal system.
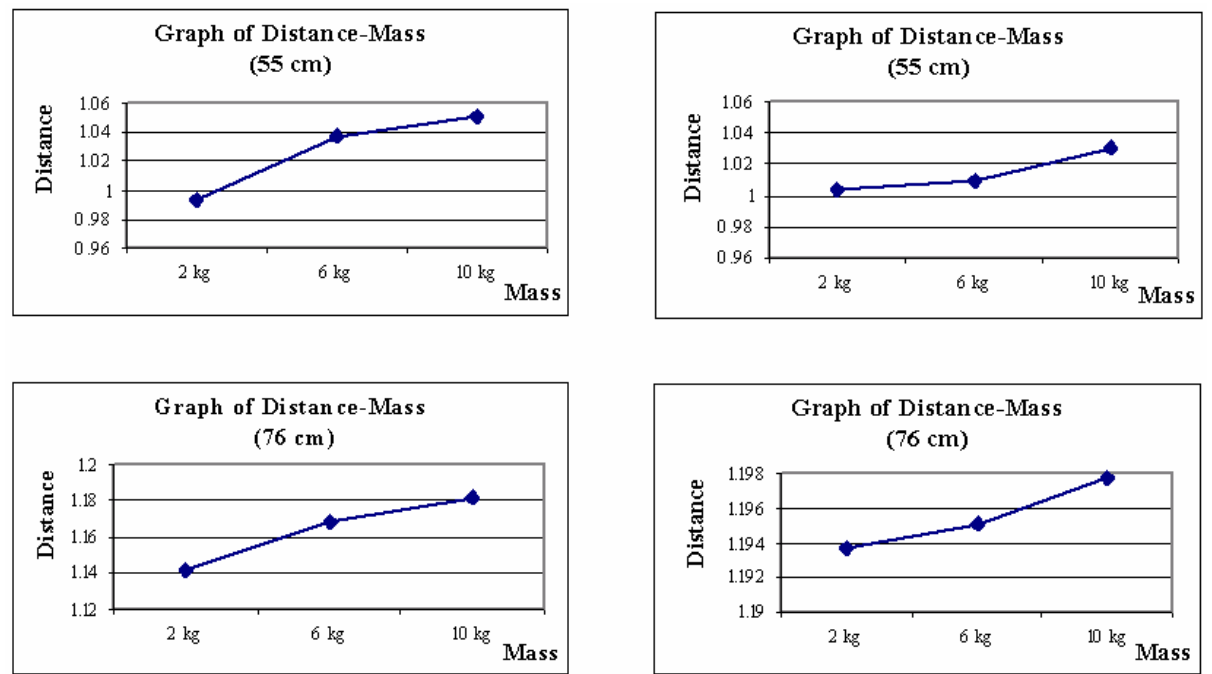

(a)

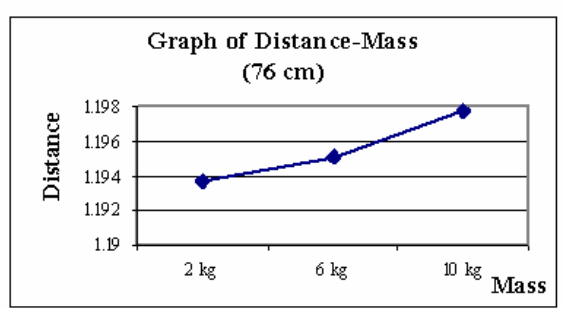

(b)

Figure 2. The effect of load to the motion path or the distance of motion;

(a) squatting posture; and (b) stooping posture

Mechanical work is identified as strengthens of the body worker for completing some tasks. It varies depend on variance at working posture and mass of load. This variance will affect the speed of motion. The bigger mechanical work the faster speed of motion such that the motion time will be shorter. It is assumed that the distance of motion is constant. Figure 4 describes the effect of mechanical work to the motion time.

On the other hand, the motion time of body worker will decrease if the mechanical work will decrease. It shows that strengthens of the body worker is al so reduced. A decrease of this mechanical work or strengthens is because of there have been energy transformation to the heat. The bigger heat is lost the longer motion time of worker for completing task. It is identified as tiredness. Besides transformation of energy, the more weight of load al so causes strengthens reduced. It is because strengthens of the body worker is limited. 

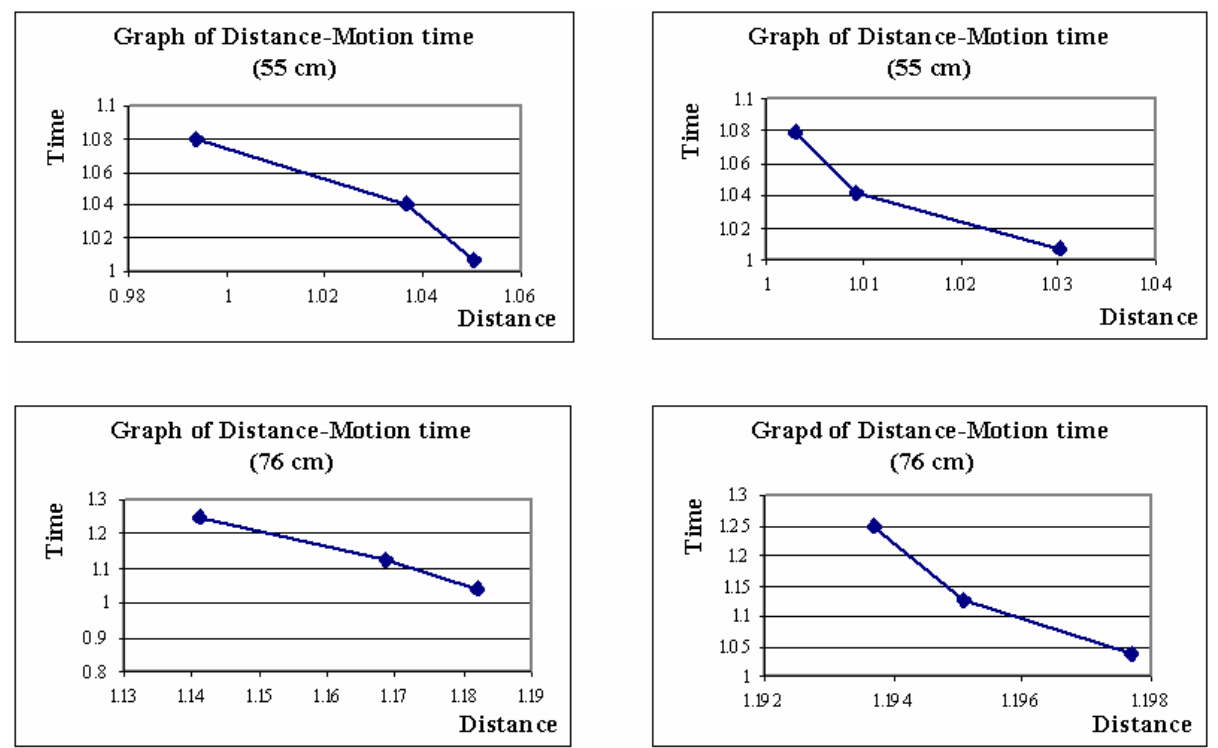

(a)

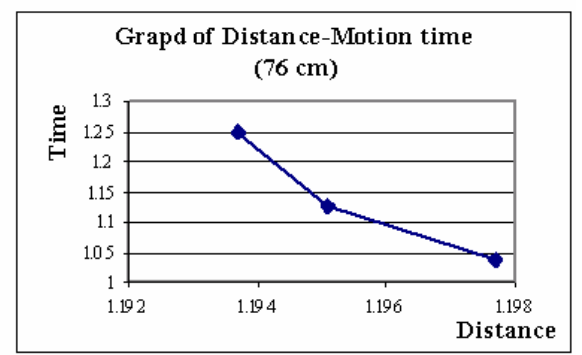

(b)

Figure 3. The effect of distance of motion to the motion time; (a) squatting posture; and (b) stooping posture
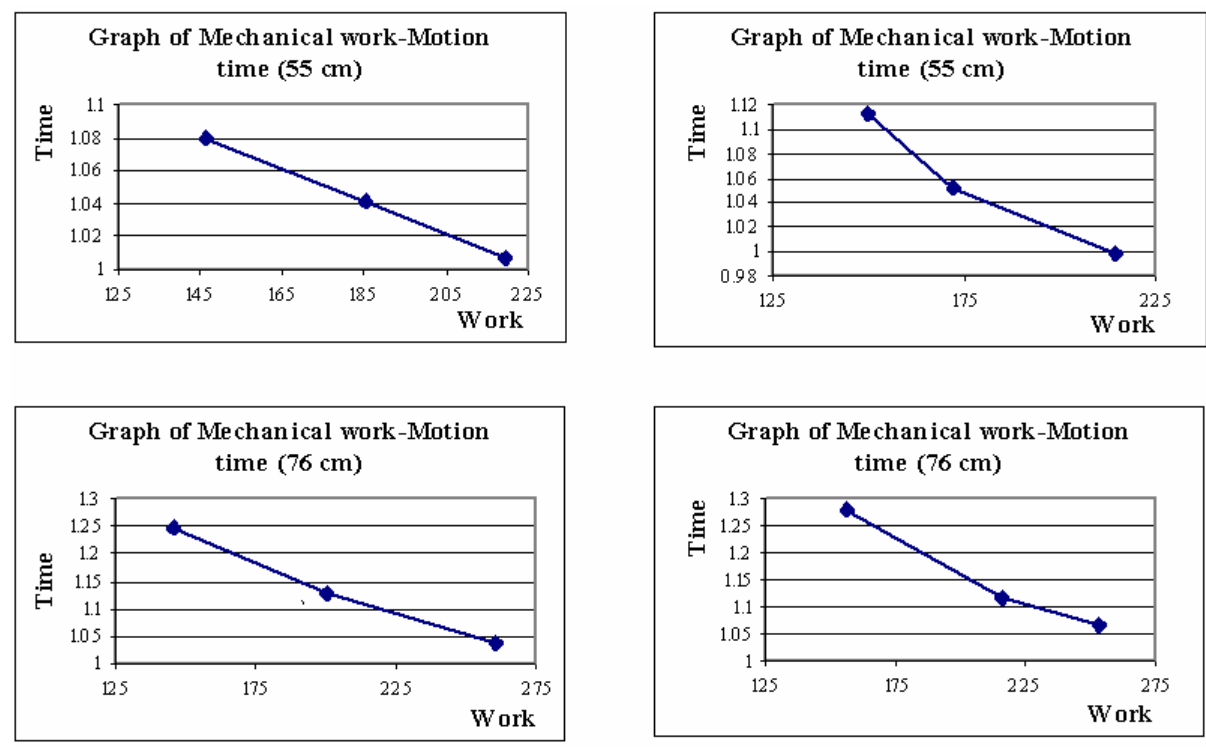

(a)

(b)

Figure 4. The effect of mechanical work to the motion time; (a) squatting posture; and (b) stooping posture 


\section{CONCLUSION}

Based on the discussion above, this study concluded that the developed model of the body motion time is affected by three variables. They are distance of motion or motion path, mass of load and mechanical work (working posture). As well as, the result from this study shows that there is no significant difference between the actual motion time and the calculated motion time by the model. It shows that the measurement model developed is valid at $1 \%, 5 \%$ and $10 \%$ significant level and could be applied to actual working motion.

\section{REFERENCES}

[1] Dempster, W.T. (1955) Space Requirements of the Seated Operator, Aerospace Medical Research Laboratories, WADC-TR-55-159, Ohio.

[2] Dul, J. and Weerdmeester, B.A. (1993) Ergonomics for Beginners: A quick Reference Guide, Taylor \& Francis, London.

[3] Hafez, H.A., and Ayoub, M.M. (1990) Lifting Speed: A Novel Perspective, Annual Report, Institute for Ergonomics Research, Texas Tech. University (unpublished).

[4] Keyserling, W.M. (1998) M ethod for Evaluating Postural Work Load, Ergonomics in $M$ anufacturing, Society Manufacturing Engineers, Michigan.

[5] Kroemer, K.H.E., Kroemer, H.B., and Kroemer-Elbert, K.E. (1994) Ergonomics How to D esign for Easy and Efficiency, Prentice-Hall, New Jersey.

[6] Leskinen, T.P.J., Stalhammar, H.R. \& Kuorinka, I.A.A. (1983) A Dynamic Analysis of Spinal Compression with Different Lifting Techniques, Ergonomics, Vol. 26, 595-604.

[7] Sanders, M.S., and McCormick, E.J. (1993) Human Factors in Engineering and Design, 7th edition, McGraw-Hill, New York.

[8] Tayyari, F., and Smith, J.L. (1997) Occupational Ergonomic; Principles and A pplications. Chapman \& Hall, London.

[9] Winter, D.A. (1979) A New Definition of Mechanical Work Done in Human Movement, Journal of A pplied Physiology, Vol. 46, 79-83.

[10]Zandin, K.B. (1990) M OST Work M easurement System, 2nd edition, Marcel Dekker, New York. 